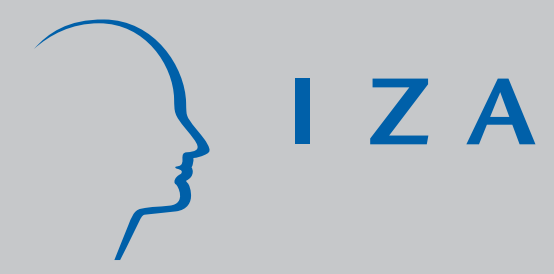

IZADP No. 1497

The Spot Market Matters:

Evidence on Implicit Contracts from Britain

Paul J. Devereux

Robert A. Hart

February 2005 


\title{
The Spot Market Matters: Evidence on Implicit Contracts from Britain
}

Paul J. Devereux

UCLA and IZA Bonn

Robert A. Hart

University of Stirling

and IZA Bonn

\author{
Discussion Paper No. 1497 \\ February 2005
}

\author{
IZA \\ P.O. Box 7240 \\ 53072 Bonn \\ Germany \\ Phone: +49-228-3894-0 \\ Fax: +49-228-3894-180 \\ Email: iza@iza.org
}

\begin{abstract}
Any opinions expressed here are those of the author(s) and not those of the institute. Research disseminated by IZA may include views on policy, but the institute itself takes no institutional policy positions.

The Institute for the Study of Labor (IZA) in Bonn is a local and virtual international research center and a place of communication between science, politics and business. IZA is an independent nonprofit company supported by Deutsche Post World Net. The center is associated with the University of Bonn and offers a stimulating research environment through its research networks, research support, and visitors and doctoral programs. IZA engages in (i) original and internationally competitive research in all fields of labor economics, (ii) development of policy concepts, and (iii) dissemination of research results and concepts to the interested public.
\end{abstract}

IZA Discussion Papers often represent preliminary work and are circulated to encourage discussion. Citation of such a paper should account for its provisional character. A revised version may be available directly from the author. 


\section{ABSTRACT \\ The Spot Market Matters: Evidence on Implicit Contracts from Britain*}

Based on the methodology of Beaudry and DiNardo (1991), this paper investigates the relative importance of the spot market and implicit contracts in the determination of British real wages. Empirical work is carried out separately for males and females with individuallevel data taken from the New Earnings Survey Panel for the years 1976 to 2001. In contrast to previous studies that used North American data, the spot market is found to be more important than implicit contracts in determining real wages. Indeed, there is very little support for implicit contracts in these data. Further evidence is provided through the analysis of individual wage sequences. These suggest that the downwardly rigid wage sequences implied by implicit contracts with costless worker mobility are not prevalent in Britain.

JEL Classification: E24, E32, J31

Keywords: $\quad$ spot market wages, implicit contracts, unemployment, wage sequences

Corresponding author:

Robert A. Hart

Department of Economics

University of Stirling

Stirling FK9 4LA

Scotland

Email: r.a.hart@stir.ac.uk

\footnotetext{
* We thank Limor Golan, Jim Malcomson, and Jonathan Thomas for helpful comments and conversations. Elizabeth Roberts provided excellent research assistance. We acknowledge the Office for National Statistics for granting access to the New Earnings Survey Panel.
} 


\section{Introduction}

Economists have long held two competing views of the employment relationship. The spot market view is that workers and firms recontract every period and compensation is largely determined by the worker's marginal product and economic conditions at that time. The alternative contracting view sees the employment relationship as more sheltered with the employer shielding the worker from the vagaries of changes in economic conditions. Okun (1981) and Bertrand (1999) describe this relationship as being governed by an "invisible handshake" characterized by an implicit understanding between parties about pay and working conditions.

Most evidence for the contracting view comes from ethnographic evidence that demonstrates how wages and promotions arise through administrative rules within firms rather than being strongly influenced by outside economic conditions (for example, Doeringer and Piore, 1971). More recently, econometric evidence has been brought to bear to demonstrate the importance of implicit contracts. By examining the relationships between wages and current and past unemployment rates, Beaudry and DiNardo (1991, henceforth BD), and Grant (2003), find evidence that implicit contracts are an important feature of U.S. labor markets. McDonald and Worswick (1999) apply the BD framework to Canadian data and find similar results.

In this paper we examine the relevance of implicit contracts in Britain using a large panel data set. We add to the literature in three main ways. First, we extend the current empirical investigations by using high quality data from outside North America. Given that the flexibility of the British labor market is somewhat similar to that in North America, it is particularly useful to see whether the North American results generalize to 
Britain. Second, our dataset contains wage data that are very clean and allow us to study whether real wage sequences are consistent with the predictions of implicit contracts. This provides a direct test of implicit contracts that complements the method in the literature of using unemployment rates. Third, we allow for the possibility that the procyclicality of promotions may be mis-interpreted as indicating the presence of implicit contracts.

Our main finding is that the spot market is the predominant influence on wages in Britain. The evidence we find for implicit contracts is weak and suggests that, at best, they play a lesser role in the labor market. This is the case whether we study the issue using unemployment rates, or look directly at wage sequences. In addition, comparing employee-job and employee-employer spells, we find indirect evidence that the procyclicality of promotions may be an important consideration.

The rest of the paper is as follows: In section 2, we describe the relevant theoretical and empirical literatures. In section 3, we describe the dataset and some descriptive statistics. In section 4, we describe our first empirical approach, and in section 5, we present the resultant coefficient estimates. In section 6, we look for evidence of implicit contracts using wage sequences. Section 7 concludes.

\section{Background Literature on Insurance Contracts}

Malcomson (1999) summarizes the implicit contract literature. The basic model of labor market insurance dates back to Azariadis (1975) and Baily (1974) who show that if an insurance contract is binding on both a risk-neutral firm and a risk-averse worker, real earnings will be invariant to idiosyncratic shocks. Thomas and Worrall (1988) extend 
these models to the situation where the contract is not binding on either party. ${ }^{1}$ In this case, the contract will only continue if doing so is in both parties interest at all points; that is, it must be self-enforcing.

BD develop these ideas further to test between the spot market, fully binding insurance contracts, and contracts in which workers can costlessly renege. First, in a spot market, only the current market conditions should impact wages so only the current unemployment rate should matter. Second, under a fully binding contract, the real wage primarily reflects the market conditions that applied when the terms of the contract were negotiated. BD capture this possibility by relating the real wage during an employment spell with a firm to the rate of unemployment that prevailed at the start of that spell. Third, if the contract is non-binding on the worker (and mobility is costless) the real wage is constant unless it becomes too low relative to market conditions to prevent a job quit. In this event, the wage is increased by an amount sufficient to counter the quit threat. This implies that wages will be determined by the best economic conditions that occur after the match begins -- BD capture this feature by allowing the wage to be affected by the minimum rate of unemployment up to the current period in the spell. Fourth, if the contract is non-binding on the company then it will cut the real wage if adverse market conditions dictate the need to otherwise layoff the worker (Malcomson, 1999). The wage is then reduced by an amount sufficient to offset such a company induced separation. BD don't allow for this possibility in their specifications but, in line with their approach, it

\footnotetext{
${ }^{1}$ Harris and Holmstrom (1982) have a related model.
} 
suggests a relationship between the real wage and the current maximum level of unemployment during an employment spell. ${ }^{2}$

Using data from the U.S. Current Population Survey (CPS) and the Panel Study of Income Dynamics (PSID), BD find that the minimum unemployment rate is strongly negatively related to current wages and the other unemployment rates are much less important. They interpret their estimates as supportive of a model in which risk averse workers are insured by their employers against business cycle shocks through implicit contracts that are binding on firms but not workers. McDonald and Worswick (1999) apply the BD framework to Canadian data and find similar results. Using six cohorts of the National Longitudinal Surveys, Grant (2003) also applies the BD framework, incorporating several refinements in the regression procedures, and again finds a significant role for the minimum unemployment rate within an employment spell.

Both BD and McDonald and Worsick find very weak evidence that the current unemployment rate affects wages once controls are included for the starting unemployment rate and the minimum unemployment rate since the job started. These results suggest that the spot market plays very little part in wage determination in the United States and Canada. Grant obtains a stronger relationship between current

\footnotetext{
${ }^{2}$ Given self enforcing contracts, Thomas and Worrall (1988) motivate the inclusion of both maximum and minimum unemployment rates. They show that for each state of the labor market there is an interval of optimal values for the contract wage. When a worker joins a firm, the wage is set within the wage interval associated with the current unemployment rate with the position depending on relative bargaining power. Changes in unemployment rate states during employment tenure produce new intervals. Successive intervals may or may not overlap. When both the firm and the worker can costlessly renege, an optimal contract requires a simple updating rule. The wage moves into the interval of the current unemployment rate state while minimising the change in the wage from the previous period. The predictions as to which unemployment rate matters for determining the wage at given period of time depends on the extent of overlap of the intervals. Sequences may occur in which the latest maximum or minimum unemployment rates matter.
} 
unemployment and the real wage and suggests that firms tend to offer wage insurance against negative shocks while wages are left to respond more flexibly at other times.

\section{Weaknesses of Unemployment Rates Approach}

While the BD approach is useful, it has the weakness that the unemployment rates could be related to wages for non-contracting reasons such as those discussed below. As a result, we implement our regression analysis at both the job and employer level, and complement our unemployment rates analysis by looking directly at wage sequences in section 6 .

\section{$\underline{\text { Jobs Versus Employers }}$}

While the empirical literature has focused on employer-employee contracts, it is plausible that much of the labor market may be governed by job-specific arrangements where wages are largely fixed to jobs and individuals with the same job in the same company typically have similar wages. ${ }^{3}$ Large changes in wages are achieved by promotions or demotions. ${ }^{4}$ This arrangement does not provide insurance to the worker against wage cuts accompanied by demotion, so it is conceptually quite distinct from insurance contracts.

Given promotions are procyclical, the minimum unemployment rate during an employer-employee spell is negatively correlated with the current wage (because the higher it is, the less likely it is that a promotion has occurred during the spell). Likewise,

\footnotetext{
${ }^{3}$ See Solon et. al. (1997) for an analysis of this idea using historical data.

${ }^{4}$ Note that this type of jobs-based organization may be advantageous for firms if workers are particularly concerned about their pay relative to others in the same job. Thus, it may be less costly for a firm to promote high ability workers to higher-level jobs rather than to increase their wages in their current job (which may lead to potentially costly disputes over relative pay and conditions among workers within the same job classification).
} 
the maximum unemployment rate should be negatively related to the current wage as demotions are more likely to occur when market conditions are bad. ${ }^{5}$ As such, the cyclical implications of the insurance contract model are observationally equivalent to the implications of the model with job-based wages and intermittent procyclical promotion, and the minimum unemployment rate results in $\mathrm{BD}$ do not necessarily speak to the relevance of implicit contracts. Given that we do not know a priori how important insurance contracts are in the British labor market, we will use both employer spells and job spells in the empirical analysis.

\section{$\underline{\text { Timing of Employer Starts }}$}

It is also possible that the starting unemployment rate may have a negative effect on wages, even in the absence of implicit contracts. People tend to get better jobs when the labor market is doing better, and hence, a lower starting unemployment rate will be associated with higher wages. Thus, the effects of the starting unemployment rate cannot be necessarily attributed to the importance of implicit contracts that are binding on firms and workers. Indeed, legally, it is unlikely that any implicit agreement could be binding on an employee. However, reputational considerations may mean these agreements are binding on employers.

\section{Data}

Our data come from the New Earnings Survey Panel Data-set (NESPD). This is a random sample of all individuals whose National Insurance numbers end in a given pair of digits (it includes a random sample of about $1 \%$ of the British working population). Each year a questionnaire is directed to employers, who complete it on the basis of payroll

\footnotetext{
${ }^{5}$ This is less likely to be important as demotions are rare.
} 
records for relevant employees. The questions relate to a specific week in April in each year. Since the same individuals are in the sample each year, the NESPD is a panel data set that runs from 1975 to the present. Employers are legally required to complete the survey questionnaire so the response rate is very high. Also, individuals can be tracked from region to region and employer to employer through time using their National Insurance numbers.

The questions in the NESPD refer primarily to earnings and hours information. Since the data are taken directly from the employer's payroll records, the earnings and hours information is considered to be very accurate. The wage measure we use is the basic (or standard) hourly rate of pay defined in the Survey as "gross weekly earnings excluding overtime divided by normal basic hours for employees whose pay for the survey period was not affected by absence." ${ }^{6}$ We deflate wages using the British Retail Price Index. ${ }^{7}$ The NESPD also includes information on age, sex, occupation, industry, collective bargaining status, and geographic location of individuals (but not education or race). The NESPD does not measure work experience so we use age as a control variable in its place. ${ }^{8}$

\footnotetext{
${ }^{6}$ Variations in wage rates within individual job spells derive overwhelmingly from earnings changes. Normal basic hours are generally constant. For example, over all male job spells, 72 percent of spells display no hours variation. As an alternative measure, taking the annual rate of change of normal hours within all male job spells, 86 percent exhibit no change. The respective female figures are 77 and 88 percent.

${ }^{7}$ We also estimated real wage specifications in which hourly earnings (including overtime) replaced hourly standard rates. These produced no substantive changes and so we confine attention to hourly standard rates throughout the paper.

${ }^{8}$ We can construct experience for a small group of individuals (3709 males and 3417 females) who enter the labour force during our sample period. For this group, we have verified that the estimates of the unemployment rate variables are robust to the inclusion of age instead of experience. The results from this
} 


\section{Sample Construction}

We restrict the sample to job spells in which individuals are (a) working full time, (b) holding a single job, and (c) not reporting that pay was influenced by absence. If someone switches from full-time to part-time, the job spell ends with the last full-time record. However, the individual could return to the sample with a new full-time job. Our sample includes most full time employees in the NESPD, covering 114 thousand males and 74 thousand females. Figure 1 shows the log real hourly wage averaged separately over all males and females in our sample together with the percentage national unemployment rate. At this highly aggregate level, the wages display a modest degree of procyclicality around a rising trend together with a narrowing of the male-female differential.

Table 1 shows the effects of our sample selection on individuals' mean and median ages. Starting from a mean age of 39 years for men and 38 years for women in the full NESPD data, the mean drops by 2 years for women by excluding part-timers and individuals whose pay is affected by absence. In order to identify tenure, we must observe a job change marker at the outset of a job. At the beginning of the NESPD, in 1975, many older workers entered the panel for the first time during a given job. The mean age of men affected in this way was 42 years and for women it was 39 years. We could only pick up these individuals as and when they subsequently changed jobs. This served to reduce the mean age of our full time workers' sample by 2 years for men and women, as shown in the third row of ages in Table 1. Similarly, when individuals leave and then re-enter the panel, many are observed for the first time during a job spell. ${ }^{9}$ Their

small sample were also broadly in line with those we present for the much larger sample we use in estimation.

${ }_{9}^{9}$ Possible reasons for departure and re-entry are (1) Persons leave the labour force and then come back (the NESPD is predicated on whether an individual is on the company payroll). (2) People switch companies 
mean ages are also relatively high -40 years for men and 38 years for women - and the elimination of these observations again reduced the mean age of men from 37 to 36 years and women from 34 to 32 years. ${ }^{10}$

\section{Measurement of Job and Employer Tenure}

Our methodology requires that we know the length of tenure within any job or employer spell. Tenure is not recorded directly in the NESPD but, for most job spells, the job change question in the survey allows us to calculate tenure on the job since it marks years in which job changes take place. ${ }^{11}$ Apart from two years, 1996 and 1997, it is not possible to distinguish directly between job moves occuring within the company and those between companies.

In order to estimate employer spells, we adopt the following simple decision rule:

A worker is deemed to have changed company if a job move coincides with a change in (1digit) industry, and/or a change in geographical region (of 11 British standard regions), and/or a switch between public and private sectors. ${ }^{12}$ Because we exclude single year spells in the analysis, we actually use more employer spells than job spells (because many unused single period job spells become part of a longer spell with employer).

and, in some cases, it takes tax authorities some time to track them down. (3) Some leave full-time employment, go part-time, and then return full-time (we just use full time spells). (4) Some leave to go to very small companies and these are not picked up in the Survey.

${ }^{10}$ Our finding that the spot market dominates is not the result of the relative youth of our sample as can be seen in section 5 where we split the sample by age.

11 The NESPD questionnaire requires employers to indicate whether an employee has worked in the same job within the organisation for one year or more. If the employee has changed to a different job or been promoted within the past 12 months then the employer is required to submit 'under one year'.

${ }^{12}$ We know that no decision rule can be completely accurate. For example, an individual can be working in the same company but in a completely different geographical location. Apart from the years 1996 and 1997, we have no information on these types of relocation. 
In Table 3, we show how well this rule performs using the 1996/1997 data (in which we can perfectly distinguish between company changers and within-company job changers). In 1997, 36741 workers remained in the same job compared to 1996 . There were 1924 actual intra-company job movers, and 1981 actual inter-company movers. Our methodology produced 1590 correct intra-company movers $(82.6 \%$ of total actual position movers - i.e. 334 or $17.4 \%$ were wrongly deemed to have changed employer). We obtained 1286 correct company movers (65\% of total actual employer movers i.e. 695 or $35 \%$ were wrongly deemed to have stayed with same employer). Other trials - for example using greater regional and industrial disaggregation - produced lower accuracy for these two years. One should note that while our coding of employer changers is not perfect, it is likely to be at least as good as that derived from self-reported tenure data such as in the PSID or CPS. ${ }^{13}$

\section{Empirical Methodology - Unemployment Rate Analysis}

Following BD, we allow wages to be a function of the contemporaneous unemployment rate, the starting unemployment rate, and the minimum unemployment rate since the job started. In addition, we allow for the possibility that wage contracts are not binding on the firm by also including a control for the maximum unemployment rate since the job started. The natural log of the wage, $\ln w$, for individual $i$ during a given job spell is expressed as follows:

$$
\ln w_{i}(s+t, s)=X_{i, s+t} \Omega_{1}+\Omega_{2} C(s, t)+\varepsilon_{i, s+t},
$$

\footnotetext{
${ }^{13}$ For example, see Brown and Light (1992) for a discussion of the ambiguities in measuring employer tenure in the PSID.
} 


$$
\begin{aligned}
& U_{s+t} \quad \text { spot wage } \\
& C(s, t)=U_{s} \quad \text { fully binding contract } \\
& \min \left\{U_{s+k}, k=0,1, \ldots, t\right\} \quad \text { non-binding on worker } \\
& \max \left\{U_{s+k}, k=0,1, \ldots, t\right\} \quad \text { non-binding on company. }
\end{aligned}
$$

The unemployment rate is denoted by $U$, with $U_{s}$ the rate prevailing at the start of the job and $U_{s+t}$ the rate at time $\mathrm{s}+t$ where $t$ denotes tenure with the employer. Individual characteristics are represented by $X ; C(s, t)$ encapsulates the unemployment rate variables. Quartic functions of age and of tenure, plus dummies for collective bargaining coverage, industry, and region are included in $X_{i}$. The error term, $\varepsilon$, is assumed to have a permanent individual-specific component $\left(\mathrm{f}_{\mathrm{i}}\right)$, and an idiosyncratic component. Note that because we use panel data, we can include individual fixed effects in equation (1) to control for permanent unobserved individual attributes that affect wages. For example, if low-skill workers are more likely to obtain jobs in booms, in the absence of fixed effects, this would induce a spurious positive correlation between the starting unemployment rate and the wage. ${ }^{14}$

The use of national-level unemployment rates alongside individual wage data raises the well-known problem of underestimated standard errors (Moulton, 1986). To correct for this problem, we estimate the regressions using a three-step approach that is a generalization of the two-step method suggested by Solon et al. (1994).

\section{First-Stage:}

In the first step, the estimation equation is as follows:

\footnotetext{
${ }^{14}$ We have also experimented with using individual-job and individual-employer fixed effects that allow individual ability to vary over time but be constant during matches between the individual and a job, or the individual and an employer, respectively. We found very similar estimates to those from individual fixed effects regressions.
} 


$$
\ln w_{i}(s+t, s)=X_{i, s+t} \Omega_{1}+\Omega_{2} \phi(s, t)+f_{i}+\varepsilon_{i, s+t}
$$

Thus, the log wage of an individual $i$ who started a job at time $s$ and has tenure $t$ is modeled as a function of personal characteristics (X), indicator variables for each possible start year - tenure combination $\phi(s, t)$, individual fixed effects $\left(\mathrm{f}_{\mathrm{i}}\right)$, and an error term. Note that the start year-tenure dummies completely control for all the unemployment rate variables -- the current unemployment rate, starting unemployment rate, and the minimum and maximum rates since the job started are the same for all individuals in the same start year-tenure cell.

The coefficients on the start year-tenure dummies, $\hat{\phi}(s, t)$, are stored and used in the second stage regressions. These coefficients can be interpreted as compositionconstant average wage rates for each start year-tenure cell given that individual fixed effects and time-varying individual characteristics have been conditioned out in equation (2).

\section{Second-Stage:}

The second stage regressions are carried out at the start year-tenure level. The

coefficients on the start year-tenure dummies, $\hat{\phi}(s, t)$, from equation (2), are regressed on a quartic in tenure, a set of year dummies, the starting unemployment rate, the minimum unemployment rate, and the maximum unemployment rate. Each second step observation is weighted by the number of individual observations in that start year-tenure cell.

\section{Third-Stage:}

Finally, the third stage regressions are carried out at the annual level. In this step, the coefficients on the year dummies from step 2 are regressed on the national 
unemployment rate and a time trend. We weight each third step observation by the number of individual observations in that year.

\section{Regression Results}

Table 3 presents individual fixed effect estimates, for both job spells and employer spells, from equations (1) and (2). As with later results, the period covered is 1976 to $2001 .^{15}$ We find statistically significant negative effects of the contemporaneous unemployment rate of about -0.013 for both the male and female samples. This implies that a one point increase in the unemployment rate reduces wages by about $1.3 \%$. The minimum unemployment rate is negative and statistically significant in all regressions but the size of the coefficients are relatively small - between -0.007 and -0.003 . Surprisingly, for women, the starting unemployment rate has a statistically significant positive effect on the wage. However, the size of the coefficient is small being .001 for job spells and .002 for employer spells. The maximum unemployment rate has no statistically significant effect on the wage.

For men, the effect of the minimum unemployment rate is a little bigger in the employer- compared to the job-spell regression, -0.004 compared to -0.003 , but the difference is statistically insignificant. However, the effect also rises for women, -0.007 compared to -0.005 and this difference is statistically significant. ${ }^{16}$ This probably reflects the fact that, at times of relatively low unemployment, firms (a) expand their business

\footnotetext{
${ }^{15}$ The start year, 1976, is chosen as we need to start from the second year of our complete data in order to determine employer spells.

${ }^{16}$ We determine the level of statistical significance by utilizing the fact that the variance of the difference is a function of the variances of the two individual estimates, and the correlation between these estimates. We have analytical estimates of the individual variances and we estimate the correlation between the two coefficients by bootstrapping.
} 
and/or (b) experience more job quits as outside opportunities improve. Both these factors serve to improve internal promotion opportunities and so the increased impacts of minimum unemployment rate within employer spells are (to some extent at least) reflecting wage increases associated with internal promotions (which would occur even in the absence of implicit contracts). As we report below, these differences in female minimum unemployment rate estimates with respect to job spells/employer spells are especially pronounced in the public sector.

\section{Heterogeneous Effects}

We now explore whether the coefficients differ across subgroups of the sample. In particular, we study the effects by occupation, by public and private sectors, by age, and by collective bargaining status.

\section{Estimates by Occupation}

Turnover costs of replacing manual employees are probably much less than those of replacing professional employees. This suggests that implicit contracts are more likely to be important in professional occupations. Theoretical motivation is provided by Malcomson (1999) who explores the use of fixed wage contracts designed to obtain efficient general human capital investments. ${ }^{17}$ He shows that such contracts can give rise to exactly the same wage dynamics as the risk-sharing model. Essentially, the parties minimise costly separations arising from potential losses of general investments by responding to the best (and worst) labor market conditions since the start of the job. The higher the associated turnover cost, ceteris paribus, the greater the gain derived from protecting investments. 
Table 4 shows estimates using a professional/manual split. ${ }^{18}$ Note that for professional males both minimum and maximum unemployment within job/employer spells play significant roles, an outcome consistent with implicit contracts that are not binding on either employees or employers. However, even for this group, the effect of the contemporaneous unemployment rate is relatively large. For professional females, the effect of the maximum unemployment rate is small and statistically insignificant, and the minimum unemployment rate has a small effect. However, the coefficient on the contemporaneous unemployment rate is very large. Thus, overall, there is no strong evidence that implicit contracts are very important in professional occupations.

The male manual results suggest that the contemporaneous unemployment rate is the primary determinant of wages for this group. The coefficients on the other unemployment rates are all very small, and only the starting unemployment rate is statistically significant. In the case of manual females, the spot market exerts a very strong effect on wages. As with their male counterparts, start unemployment is a strong influence on the wages of manual females. In two further instances, however, the manual female results diverge from their male equivalents. Minimum unemployment has a sizeable negative impact on manual female wages. Further, maximum unemployment has a significant and large positive association with manual female wages. We do not understand this result.

\footnotetext{
${ }_{17}^{17}$ See also MacLeod and Malcomson (1993).

${ }^{18}$ In our NESPD samples, $18.2 \%$ of males and $19.9 \%$ of females are classified as professional workers while $49.9 \%$ of males and $17 \%$ of females are manual workers. Professionals include both professional occupations (such as natural scientists, engineers, health professionals, teachers, legal professionals, business and finance professionals) and associate professional and technical occupations (such as scientific technicians, computer analysts/programmers, health associate professionals, business and finance associate professionals). Thoughout all occupations, the NESPD contains sub-group markers that denote workers with manual status.
} 


\section{Estimates by Private and Public Sectors}

We might expect implicit contracts to be relatively unimportant among public sector workers because pay and working conditions are generally explicit and transparent with employees in similar jobs on consistent pay scales. Monitoring of employment conditions across the public sector is enhanced by a relatively high degree of collective bargaining coverage. ${ }^{19}$ Additionally, laid down rules and regulations within extremely large and complex public sector industries - such as the health service, postal service, local and central government - avoid the bargaining and industrial relations costs of negotiating pay and conditions at relatively local levels.

Table 5 contains the private/public sector splits. ${ }^{20}$ The strongest finding is that the current unemployment rate is dominant in both sectors. Whether one looks at job spells or employer spells, the only unemployment rate variable with a sizeable coefficient for men is the current unemployment rate. Thus, for men, there is no evidence for implicit contracting effects in either sector. For women, there is evidence that the minimum unemployment rate also impacts wages, but the coefficient is much smaller than that on the current unemployment rate.

Especially interesting results in Table 5 pertain to public sector employer spell regressions in comparision with equivalent job spell specifications. The female minimum unemployment rate coefficient within employer spells is -0.006 (significant at the 1 percent level) compared to -0.001 (insignificant) using job spells. In times of economic expansions, public sector employers may have more recourse to using internal

\footnotetext{
${ }^{19}$ In our full NESPD sample, 87 percent of males and 88 percent of females in the public sector are covered by collective bargaining agreements. This contrasts with 27 and 20 percent, respectively, in the private sector.

${ }^{20}$ The public sector covers employees in central government, local government, and public corporations.
} 
promotions as a means of preventing losses of key personnel to the private sector. This would be picked up by the minimum unemployment rate in our employer-spells specification. In our complete data, 37 percent of females are in the public sector. Therefore, our general finding among females of statistically significant increases in the coefficient on the minimum unemployment rate within employer- compared to job-spells reported in Table 3 is driven by these public sector differences.

\section{Estimates by Age}

We also divided our data into younger and older workers, defined in terms of whether younger than or at/above the median age (the age here is the age at the beginning of the job or employment spell). ${ }^{21}$ Results are reported in Table 6. As before, contemporary unemployment is the strongest influence on the wage for all groups. Also, the minimum unemployment rate has little impact on the wages of men above the median age, but has a strong relationship for young men. This implies that, to the extent that downwardly-rigid insurance contracts are important, they are not relevant to older men. There are similar age differences for females, except here there is also a significant minimum unemployment rate effect for older females. Another noticeable feature of Table 6 concerns older males and females. Changing from job- to employer- spells for these groups increases the significance of maximum unemployment. As with minimum unemployment discussed earlier, this may simply derive from the impact of internal company demotions on the wage rather than reflecting a role of implicit contracts.

\footnotetext{
${ }^{21}$ We explain in the discussion relating to Table 1 why the median ages are relatively low in our panel.
} 


\section{Estimates by Collective Bargaining Status}

Hogan (2001) suggests that unions provide a mechanism that allows the implementation of implicit contracts. This suggests that one might find differences across collective bargaining status. We investigate this issue in Table 7. Note, that collective bargaining status is more broadly defined than union membership as some non-members are covered by union contracts (throughout our NESPD data, on average $43.1 \%$ of males and $45.2 \%$ of females are covered). ${ }^{22}$ Unfortunately, the quality of the coverage data in the NESPD is in some doubt because there are a number of large swings in coverage from year to year. Thus, the results below should be treated with caution.

We find that, once again, the spot market dominates -- it does not appear that collective bargaining provides protection from cyclical market forces. The contemporaneous unemployment rate is the only significant variable for covered men. There is some evidence that the minimum unemployment rate also matters for uncovered men. For females, the minimum unemployment rate matters for both covered and uncovered employers, and the maximum unemployment rate has a significantly negative effect for uncovered females. Overall, these results provide little support for Hogan's proposition that unions enable the implementation of implicit contracts. They are also in line with our reported public sector findings (see Table 5) where collective bargaining coverage is especially strong and where little support for implicit contracts is obtained.

\footnotetext{
$2245.8 \%$ of manual males are covered and nearly the same percentage, $43.1 \%$, of professional males are covered. $68.1 \%$ of professional females (teachers and civil servants are prominent here) are covered in contrast to only $37.7 \%$ of manual females.
} 


\section{Evidence from Wage Sequences}

While the cyclical implications of the insurance contract model have been empirically examined in the literature, a more direct implication relates to wage sequences (see Malcomson, 1999). In a fully binding contract, the real wage is rigid. ${ }^{23}$ In a contract that is not binding on the employee but is binding on the firm, real wages within employeremployee matches are downwardly rigid. If there is a spot market or if the insurance contract is not binding on either party real wages may rise or fall during the match. Because our wage data is likely measured with very little error, we can directly examine whether the wage sequences we observe in the data are consistent with the implications of the models. In particular, if workers actually do have downwardly rigid wage contracts, this should be clearly observable in the data. In this section, we disaggregate employer spells by length of spell and, for each spell length, we tabulate the proportions that have

(a) downwardly rigid wages,

(b) upwardly rigid wages,

(c) constant wages,

(d) both wage increases and wage cuts.

We treat a real wage change as being constant if it does not change by more than $1 \%{ }^{24}$ Results with respect to job-spells and employer-spells are shown, respectively, in Tables 8 and 9 and differ only marginally. We find that very few spells are characterized by real wages that remain constant from year to year, an outcome that is not supportive of

\footnotetext{
${ }^{23}$ As is discussed below, this may not be an implication of the model if worker ability changes over time.
} 
insurance contracts that are binding on both parties. As discussed in section 2, this is unsurprising as implicit contracts are not legally binding on employees.

Also, comparatively few spells are characterized by downwardly rigid or upwardly rigid real wages, especially once one considers spells that last at least 6 years. The lack of pervasive evidence of downwardly rigid patterns is inconsistent with contracts that are binding on employers but not on employees. Most spells have periods of rising wages and periods of falling wages. ${ }^{25}$ Of course, it is impossible from these sequences to rule out contracts that do not bind on either party as these can imply frequent upward and downward wage adjustment. However, the earlier regression analysis (especially the coefficient on the maximum unemployment rate) sheds doubt on the relevance of these types of contracts.

As mentioned above, the assumption required to draw inferences from wage sequences is that ability is fixed within matches. While this constant ability assumption underlies the earlier fixed effects wage regressions, violations of the assumption are likely to have more severe repercussions when studying wage sequences. One would expect that individuals acquire general human capital, firm-specific human capital, and job-specific human capital over time. This implies that wages rise with firm and job tenure. This type of wage growth biases our analysis towards finding downwardly rigid wage sequences, as these will be a consequence of human capital accumulation. The implication is that our failure to find evidence that downwardly rigid wage sequences are

\footnotetext{
${ }^{24} \mathrm{We}$ allow for a $1 \%$ margin of error in wages to allow for unexpected shocks that may take some time to address such as discrepancies between expected and actual inflation.

${ }^{25}$ Even when one looks at nominal wage sequences, over 80 percent of spells lasting between 6 and 10 years have both increases and decreases in nominal wages. Thus, our real wage results cannot be explained by unexpected shocks to the rate of inflation.
} 
predominant is even less supportive of implicit contracting models, once this source of wage change is taken into account.

\section{Conclusions}

Our main finding is that, unlike previous evidence for the U.S. and Canada, the spot market appears to be important in Britain - our most robust finding is that wages are negatively influenced by higher current rates of unemployment. By contrast, the evidence for important effects of the starting unemployment rate, or minimum or maximum unemployment rates is quite weak. We augment this evidence by utilizing our high quality data to study wage sequences and similarly find little evidence that the downwardly-rigid sequences predicted by the theory are prevalent. Taken together, these two pieces of evidence suggest that insurance contracts do not play a large role in the British labor market.

We have also considered the possibility that the procyclicality of promotions may make it difficult to identify the presence of implicit contracts in the BD framework. Our comparison of job-based and employer-based minimum unemployment estimates suggests that the latter are in part capturing wage effects stemming from the proyclicality of promotions. Of course, it may be that promotions are understood as an integral part of implicit understandings between employers and employees. However, the large lumpy wage changes on promotion are inconsistent with existing insurance contract models that see wages increasing by just the amount sufficient to keep both parties in the match. This is clearly an area worthy of further theoretical and empirical investigation. 


\section{References}

Azariadis, Costas. 1975. "Implicit Contracts and underemployment Equilibria." Journal of Political Economy, Vol. 83, pp. 1183-1202.

Baily, Martin N. 1974. "Wages and Employment under uncertain demand." Review of Economic Studies, Vol. 41, pp. 37-50.

Beaudry, P and J DiNardo (1991). "The effect of implicit contracts on the movement of wages over the business cycle: evidence from micro data." Journal of Political Economy 99: 665-688.

Bertrand, Marianne (1999). "From the Invisible Handshake to the Invisible Hand? How Import Competition Changes the Employment Relationship." NBER Working Paper \#6900.

Brown, James and Audrey Light (1992). “Interpreting Panel Data on Job Tenure” Journal of Labor Economics 10(3), 219-257.

Doeringer, Peter and Michael Piore. 1971. Internal labor markets and manpower analysis. Lexington, MA: DC Heath.

Grant, D. 2003. "The effect of implicit contracts on the movement of wages over the business cycle: evidence for the National Longitudinal Surveys." Industrial and Labor Relations Review 56: 393-408.

Harris, M and B Holmstrom. 1982. “A theory of wage dynamics.” Review of Economic Studies 49: 315-333.

Hogan, Chad. 2001. "Enforcement of Implicit Employment Contracts Through Unionization.” Journal of Labor Economics. 19(1), January: 171-95. 
MacLeod, W.B., and J.M. Malcomson. 1993. "Investments, Holdup, and the Form of Market Contracts.” American Economic Review, 83(4): 811-837.

Malcomson, J M. 1999. “Individual employment contracts.” Handbook of Labor Economics Vol. 3B (Eds. O Ashenfelter and D Card): Chpt. 35, 2291-2372.

McDonald James Ted, and Christopher Worswick (1999). "Wages, Implicit Contracts and the Business Cycle: Evidence from Canadian Micro Data." Journal of Political Economy, 107(4), August: 884-892.

Moulton, B R. 1986. "Random group effects and the precision of regression estimates." Journal of Econometrics 32: 385-397.

Okun, Arthur M., 1981, Prices and Quantities: A Macroeconomic Analysis, Washington: Brookings Institution.

Thomas, J and T Worrall. 1988. "Self-enforcing wage contracts.” Review of Economic Studies 55: 541-553.

Solon, G R, Barsky, and J A Parker. 1994. "Measuring the cyclicality of real wages: how important is composition bias?" Quarterly Journal of Economics 109: 1-26.

Solon, Gary, Whatley, Warren, and Ann Huff Stevens. 1997. "Wage Changes and Intrafirm Job Mobility over the Business Cycle: Two case studies.” Industrial and Labor Relations Review, Vol. 50, No. 70, pp. 402-415. 
Figure 1: Average Log Real Wages (Males and Females) and Unemployment Rate

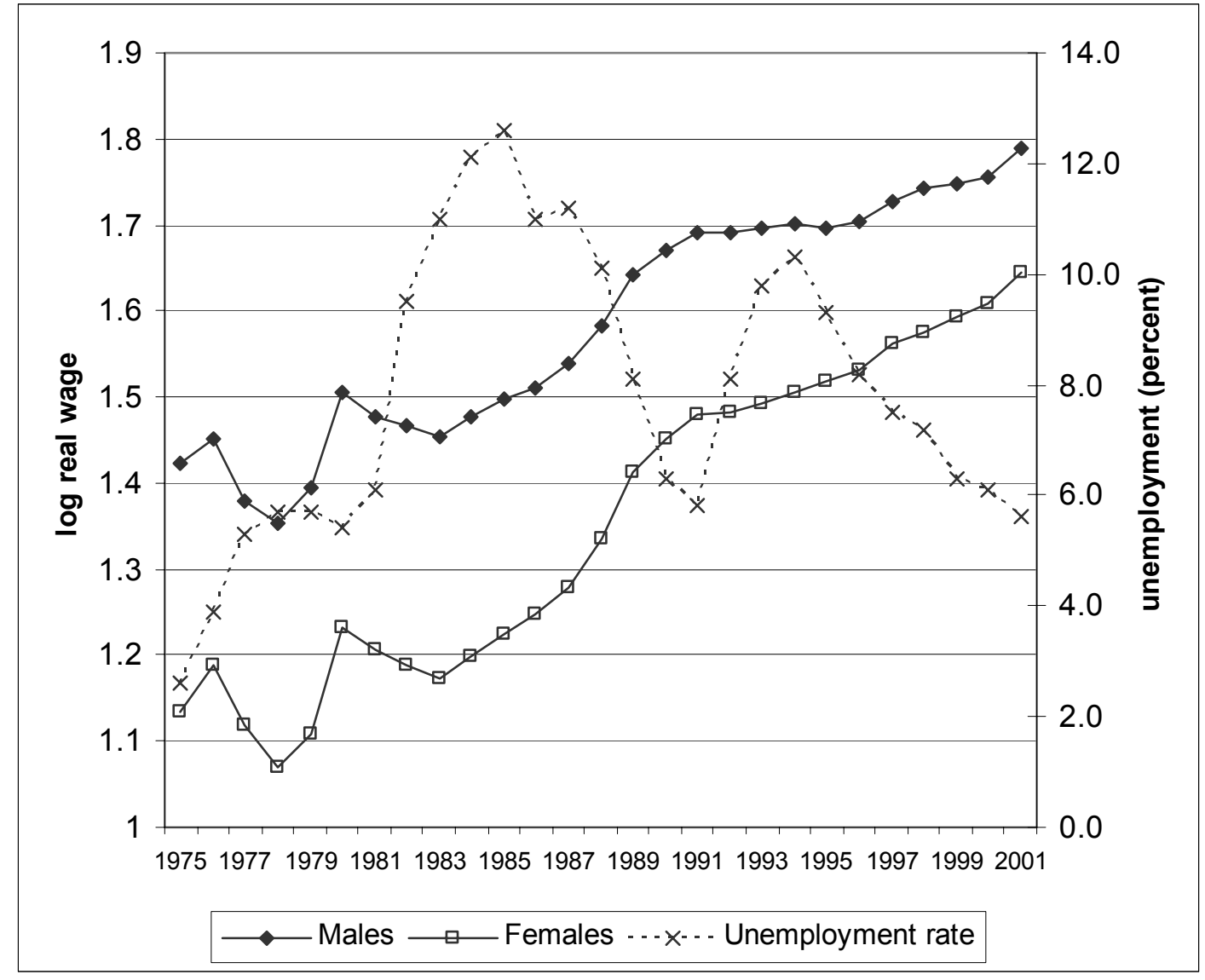

Table 1: Median and Mean Ages of Males and Females in NESPD Samples

\begin{tabular}{|l|c|c|c|c|}
\hline NESPD SAMPLE & \multicolumn{2}{|c|}{ Male ages } & \multicolumn{2}{c|}{ Female ages } \\
\hline & Mean & Median & Mean & Median \\
\hline Full NESPD 1975 - 2001 & 39 & 38 & 38 & 38 \\
\hline $\begin{array}{l}\text { Restricting sample to full time workers } \\
\text { whose pay is not affected by absence }\end{array}$ & 39 & 39 & 36 & 34 \\
\hline $\begin{array}{l}\text { Eliminating individuals whose first } \\
\text { observed job does not start with a job } \\
\text { change marker }\end{array}$ & 37 & 36 & 34 & 31 \\
\hline $\begin{array}{l}\text { Eliminating returning individuals } \\
\text { whose first observed job does not start } \\
\text { with a job start marker }\end{array}$ & 36 & 34 & 32 & 29 \\
\hline
\end{tabular}


Table 2: Actual and Simulated Job Sequences Between 1996 and 1997

\begin{tabular}{|l|c|c|c|c|}
\hline Actual job sequence & \multicolumn{4}{|c|}{ Simulated job sequence } \\
\hline & Same job & $\begin{array}{c}\text { Same } \\
\text { company }\end{array}$ & $\begin{array}{c}\text { New } \\
\text { company }\end{array}$ & Total \\
\hline Same job & 36741 & 0 & 0 & 36741 \\
\hline Same company & 0 & 1590 & 334 & 1924 \\
\hline New company & 0 & 695 & 1286 & 1981 \\
\hline Total & 36741 & 2285 & 1620 & 40646 \\
\hline
\end{tabular}

Table 3: Real Wages and Unemployment Within Job Spells, 1976-2001 Full Male and Female Samples

\begin{tabular}{|lcccc|c|}
\hline & $\begin{array}{l}\text { Contemporaneous } \\
\text { unemployment } \\
\text { rate }\end{array}$ & $\begin{array}{l}\text { Unemployment } \\
\text { rate at start of } \\
\text { job }\end{array}$ & $\begin{array}{l}\text { Minimum } \\
\text { unemployment } \\
\text { rate since job } \\
\text { start }\end{array}$ & $\begin{array}{l}\text { Maximum } \\
\text { unemployment } \\
\text { rate since job } \\
\text { start }\end{array}$ & $\begin{array}{l}\text { No. of } \\
\text { individuals } \\
\text { (observations) }\end{array}$ \\
\hline Males & $-0.013^{* *}$ & -0.0009 & $-0.003^{*}$ & 0.0001 & 114598 \\
Females & $(0.002)$ & $(0.0005)$ & $(0.001)$ & $(0.002)$ & $(752180)$ \\
& $-0.013^{* *}$ & $0.001^{* *}$ & $-0.005^{* *}$ & -0.002 & 74524 \\
& $(0.003)$ & $(0.0004)$ & $(0.0008)$ & $(0.001)$ & $(423547)$ \\
\hline Males & $-0.012^{* *}$ & 0.0009 & $-0.004^{* *}$ & -0.001 & 113128 \\
& $(0.002)$ & $(0.0006)$ & $(0.001)$ & $(0.002)$ & $(750710)$ \\
Females & $-0.013^{* *}$ & $0.002 * *$ & $-0.007 * *$ & -0.002 & 73499 \\
& $(0.003)$ & $(0.0004)$ & $(0.001)$ & $(0.001)$ & $(422522)$ \\
& & & & & \\
\hline
\end{tabular}

Notes: These individual fixed effects estimates are derived from the three-stage procedure outlined in Section 4. First stage regressions are based on the numbers of individuals/observations shown in last column. Second stage estimates are derived from 377 or 376 observations. Third stage estimates are all based on 26 observations. Robust standard errors in brackets. **(*) Denotes coefficients significant at $0.01(0.05)$ level (two-tailed test). Additional variables include age (quartic), job tenure (quartic), collective agreement dummy, industry, and region. 
Table 4: Real wages and Unemployment Within Job Spells, 1976-2001 Professional and Manual Occupations

\begin{tabular}{|c|c|c|c|c|c|}
\hline & $\begin{array}{l}\text { Contemporaneous } \\
\text { unemployment rate }\end{array}$ & $\begin{array}{l}\text { Unemployment } \\
\text { rate at start of } \\
\text { job }\end{array}$ & $\begin{array}{l}\text { Minimum } \\
\text { unemployment } \\
\text { rate since job } \\
\text { start }\end{array}$ & $\begin{array}{l}\text { Maximum } \\
\text { unemployment } \\
\text { rate since job } \\
\text { start }\end{array}$ & $\begin{array}{l}\text { No. of } \\
\text { individuals } \\
\text { (observations) }\end{array}$ \\
\hline \multicolumn{6}{|c|}{ Job spells } \\
\hline $\begin{array}{l}\text { Professional } \\
\text { (males) }\end{array}$ & $\begin{array}{c}-0.008 * * \\
(0.003)\end{array}$ & $\begin{array}{c}0.0006 \\
(0.0008)\end{array}$ & $\begin{array}{c}-0.005^{* *} \\
(0.001)\end{array}$ & $\begin{array}{c}-0.004 * * \\
(0.001)\end{array}$ & $\begin{array}{c}26411 \\
(111585)\end{array}$ \\
\hline $\begin{array}{l}\text { Professional } \\
\text { (females) }\end{array}$ & $\begin{array}{c}-0.017 * * \\
(0.004)\end{array}$ & $\begin{array}{c}-0.001 \\
(0.002)\end{array}$ & $\begin{array}{c}-0.003 * \\
(0.002)\end{array}$ & $\begin{array}{c}0.001 \\
(0.002)\end{array}$ & $\begin{array}{c}18707 \\
(74695)\end{array}$ \\
\hline $\begin{array}{l}\text { Manual } \\
\text { (males) }\end{array}$ & $\begin{array}{c}-0.013 * * \\
(0.002)\end{array}$ & $\begin{array}{c}-0.003 * * \\
(0.0006)\end{array}$ & $\begin{array}{c}-0.0006 \\
(0.001)\end{array}$ & $\begin{array}{c}0.002 \\
(0.002)\end{array}$ & $\begin{array}{c}71041 \\
(357883)\end{array}$ \\
\hline $\begin{array}{l}\text { Manual } \\
\text { (females) }\end{array}$ & $\begin{array}{c}-0.015 * * \\
(0.002)\end{array}$ & $\begin{array}{c}-0.003 * \\
(0.001)\end{array}$ & $\begin{array}{c}-0.006^{* *} \\
(0.002)\end{array}$ & $\begin{array}{c}0.007 * * \\
(0.002)\end{array}$ & $\begin{array}{c}20076 \\
(68040)\end{array}$ \\
\hline \multicolumn{6}{|c|}{ Employer spells } \\
\hline $\begin{array}{l}\text { Professional } \\
\text { (males) }\end{array}$ & $\begin{array}{c}-0.008 * * \\
(0.003)\end{array}$ & $\begin{array}{c}0.003 * * \\
(0.001)\end{array}$ & $\begin{array}{c}-0.007 * * \\
(0.002)\end{array}$ & $\begin{array}{c}-0.004^{*} \\
(0.002)\end{array}$ & $\begin{array}{c}17735 \\
(89742)\end{array}$ \\
\hline $\begin{array}{l}\text { Professional } \\
\text { (females) }\end{array}$ & $\begin{array}{c}-0.015^{* *} \\
(0.004)\end{array}$ & $\begin{array}{c}0.001 \\
(0.001)\end{array}$ & $\begin{array}{c}-0.004^{*} \\
(0.002)\end{array}$ & $\begin{array}{c}-0.002 \\
(0.002)\end{array}$ & $\begin{array}{c}13590 \\
(64305)\end{array}$ \\
\hline $\begin{array}{l}\text { Manual } \\
\text { (males) }\end{array}$ & $\begin{array}{c}-0.011 * * \\
(0.002)\end{array}$ & $\begin{array}{l}-0.002 * \\
(0.0007)\end{array}$ & $\begin{array}{r}-0.0007 \\
(0.001)\end{array}$ & $\begin{array}{c}-0.002 \\
(0.002)\end{array}$ & $\begin{array}{c}61700 \\
(336847)\end{array}$ \\
\hline $\begin{array}{l}\text { Manual } \\
\text { (females) }\end{array}$ & $\begin{array}{c}-0.017 * * \\
(0.002)\end{array}$ & $\begin{array}{c}-0.005 * * \\
(0.001)\end{array}$ & $\begin{array}{l}-0.006^{*} \\
(0.002)\end{array}$ & $\begin{array}{c}0.010 * * \\
(0.003)\end{array}$ & $\begin{array}{c}15239 \\
(61132)\end{array}$ \\
\hline
\end{tabular}

Notes: See notes to Table 3. Second stage estimates are derived from between 351 and 376 observations. 
Table 5: Real wages and Unemployment within Job Spells, 1975-2001 Private and public sector occupations

\begin{tabular}{|c|c|c|c|c|c|}
\hline & $\begin{array}{l}\text { Contemporaneous } \\
\text { unemployment } \\
\text { rate }\end{array}$ & $\begin{array}{l}\text { Unemployment } \\
\text { rate at start of } \\
\text { job }\end{array}$ & $\begin{array}{l}\text { Minimum } \\
\text { unemployment } \\
\text { rate since job } \\
\text { start }\end{array}$ & $\begin{array}{l}\text { Maximum } \\
\text { unemployment } \\
\text { rate since job } \\
\text { start }\end{array}$ & $\begin{array}{l}\text { No. of } \\
\text { individuals } \\
\text { (observations) }\end{array}$ \\
\hline \multicolumn{6}{|c|}{$\begin{array}{l}\text { Job spells } \\
\end{array}$} \\
\hline $\begin{array}{l}\text { Males } \\
\text { (private) }\end{array}$ & $\begin{array}{c}-0.015 * * \\
(0.002)\end{array}$ & $\begin{array}{l}-0.001 * \\
(0.001)\end{array}$ & $\begin{array}{c}-0.002 \\
(0.001)\end{array}$ & $\begin{array}{l}0.0004 \\
(0.001)\end{array}$ & $\begin{array}{c}93269 \\
(522045)\end{array}$ \\
\hline $\begin{array}{l}\text { Males } \\
\text { (public) }\end{array}$ & $\begin{array}{c}-0.013 * * \\
(0.003)\end{array}$ & $\begin{array}{c}-0.001 \\
(0.0007)\end{array}$ & $\begin{array}{l}-0.0009 \\
(0.001)\end{array}$ & $\begin{array}{c}0.002 \\
(0.002)\end{array}$ & $\begin{array}{c}35421 \\
(178175)\end{array}$ \\
\hline $\begin{array}{l}\text { Females } \\
\text { (private) }\end{array}$ & $\begin{array}{c}-0.012 * * \\
(0.002)\end{array}$ & $\begin{array}{l}0.003 * * \\
(0.0006)\end{array}$ & $\begin{array}{c}-0.007 * * \\
(0.001)\end{array}$ & $\begin{array}{c}-0.003 * * \\
(0.001)\end{array}$ & $\begin{array}{c}53936 \\
(258979)\end{array}$ \\
\hline $\begin{array}{l}\text { Females } \\
\text { (public) }\end{array}$ & $\begin{array}{c}-0.019 * * \\
(0.004)\end{array}$ & $\begin{array}{l}-0.003 * * \\
(0.0006)\end{array}$ & $\begin{array}{l}-0.001 \\
(0.001)\end{array}$ & $\begin{array}{l}0.004 * * \\
(0.002)\end{array}$ & $\begin{array}{c}30117 \\
(147737)\end{array}$ \\
\hline \multicolumn{6}{|c|}{ Employer spells } \\
\hline $\begin{array}{l}\text { Males } \\
\text { (private) }\end{array}$ & $\begin{array}{c}-0.014 * * \\
(0.002)\end{array}$ & $\begin{array}{l}0.0003 \\
(0.0007)\end{array}$ & $\begin{array}{c}-0.002 \\
(0.001)\end{array}$ & $\begin{array}{l}-0.002 \\
(0.002)\end{array}$ & $\begin{array}{c}86437 \\
(511555)\end{array}$ \\
\hline $\begin{array}{l}\text { Males } \\
\text { (public) }\end{array}$ & $\begin{array}{c}-0.011 * * \\
(0.003)\end{array}$ & $\begin{array}{c}0.001 * \\
(0.0006)\end{array}$ & $\begin{array}{l}-0.002 * \\
(0.001)\end{array}$ & $\begin{array}{l}-0.001 \\
(0.002)\end{array}$ & $\begin{array}{c}28386 \\
(167762)\end{array}$ \\
\hline $\begin{array}{l}\text { Females } \\
\text { (private) }\end{array}$ & $\begin{array}{c}-0.012 * * \\
(0.002)\end{array}$ & $\begin{array}{l}0.002 * * \\
(0.0007)\end{array}$ & $\begin{array}{c}-0.007 * * \\
(0.001)\end{array}$ & $\begin{array}{l}-0.002 \\
(0.002)\end{array}$ & $\begin{array}{c}48974 \\
(252938)\end{array}$ \\
\hline $\begin{array}{l}\text { Females } \\
\text { (public) }\end{array}$ & $\begin{array}{c}-0.019 * * \\
(0.004)\end{array}$ & $\begin{array}{l}-0.0004 \\
(0.0006)\end{array}$ & $\begin{array}{c}-0.006^{* *} \\
(0.001)\end{array}$ & $\begin{array}{l}0.004 * \\
(0.002)\end{array}$ & $\begin{array}{c}25589 \\
(141958)\end{array}$ \\
\hline
\end{tabular}

Notes: See notes to Table 3. Second stage estimates are derived from between 369 and 377 observations. 
Table 6: Real Wages and Unemployment Within Job Spells, 1975-2001 Above and Below Median Ages

\begin{tabular}{|c|c|c|c|c|c|}
\hline & $\begin{array}{l}\text { Contemporaneous } \\
\text { unemployment } \\
\text { rate }\end{array}$ & $\begin{array}{l}\text { Unemployment } \\
\text { at start of job }\end{array}$ & $\begin{array}{l}\text { Minimum } \\
\text { unemployment } \\
\text { rate since job } \\
\text { start }\end{array}$ & $\begin{array}{l}\text { Maximum } \\
\text { unemployment } \\
\text { rate since job } \\
\text { start }\end{array}$ & $\begin{array}{l}\text { No. of } \\
\text { individuals } \\
\text { (observations) }\end{array}$ \\
\hline \multicolumn{6}{|c|}{ Job spells } \\
\hline $\begin{array}{l}\text { Males } \\
<34\end{array}$ & $\begin{array}{c}-0.012 * * \\
(0.002)\end{array}$ & $\begin{array}{l}-0.0002 \\
(0.0007)\end{array}$ & $\begin{array}{c}-0.010^{* *} \\
(0.001)\end{array}$ & $\begin{array}{c}0.002 \\
(0.001)\end{array}$ & $\begin{array}{c}74422 \\
(412658)\end{array}$ \\
\hline $\begin{array}{l}\text { Males } \\
\geq 34\end{array}$ & $\begin{array}{c}-0.009 * * \\
(0.003)\end{array}$ & $\begin{array}{l}-0.002 * \\
(0.0009)\end{array}$ & $\begin{array}{l}-0.0005 \\
(0.001)\end{array}$ & $\begin{array}{l}0.0007 \\
(0.002)\end{array}$ & $\begin{array}{c}64053 \\
(339522)\end{array}$ \\
\hline $\begin{array}{l}\text { Females } \\
<29\end{array}$ & $\begin{array}{c}-0.012 * * \\
(0.002)\end{array}$ & $\begin{array}{c}0.001 \\
(0.0007)\end{array}$ & $\begin{array}{c}-0.010 * * \\
(0.001)\end{array}$ & $\begin{array}{l}-0.001 \\
(0.001)\end{array}$ & $\begin{array}{c}49224 \\
(230022)\end{array}$ \\
\hline $\begin{array}{l}\text { Females } \\
\geq 29\end{array}$ & $\begin{array}{c}-0.011 * * \\
(0.003)\end{array}$ & $\begin{array}{l}0.001 * * \\
(0.0004)\end{array}$ & $\begin{array}{l}-0.004 * * \\
(0.0008)\end{array}$ & $\begin{array}{l}0.0008 \\
(0.001)\end{array}$ & $\begin{array}{c}39718 \\
(193525)\end{array}$ \\
\hline \multicolumn{6}{|c|}{ Employer spells } \\
\hline $\begin{array}{l}\text { Males } \\
<34\end{array}$ & $\begin{array}{c}-0.013 * * \\
(0.002)\end{array}$ & $\begin{array}{l}0.0009 \\
(0.0007)\end{array}$ & $\begin{array}{c}-0.010 * * \\
(0.001)\end{array}$ & $\begin{array}{c}0.001 \\
(0.001)\end{array}$ & $\begin{array}{c}69445 \\
(423150)\end{array}$ \\
\hline $\begin{array}{l}\text { Males } \\
\geq 34\end{array}$ & $\begin{array}{c}-0.006 * * \\
(0.003)\end{array}$ & $\begin{array}{c}0.001 \\
(0.0008)\end{array}$ & $\begin{array}{l}-0.002 \\
(0.001)\end{array}$ & $\begin{array}{l}-0.004 * \\
(0.002)\end{array}$ & $\begin{array}{c}55072 \\
(317400)\end{array}$ \\
\hline $\begin{array}{l}\text { Females } \\
<29\end{array}$ & $\begin{array}{c}-0.013 * * \\
(0.002)\end{array}$ & $\begin{array}{l}0.002 * * \\
(0.0008)\end{array}$ & $\begin{array}{c}-0.012 * * \\
(0.001)\end{array}$ & $\begin{array}{c}-0.00001 \\
(0.001)\end{array}$ & $\begin{array}{c}45777 \\
(234751)\end{array}$ \\
\hline $\begin{array}{l}\text { Females } \\
\geq 29\end{array}$ & $\begin{array}{c}-0.008 * * \\
(0.003)\end{array}$ & $\begin{array}{l}0.004 * * \\
(0.0006)\end{array}$ & $\begin{array}{c}-0.006^{* *} \\
(0.001)\end{array}$ & $\begin{array}{l}-0.003 * \\
(0.002)\end{array}$ & $\begin{array}{c}33508 \\
(180666)\end{array}$ \\
\hline
\end{tabular}

Notes: See notes to Table 3. Second stage estimates are derived from between 374 and 377 observations. 
Table 7: Real wages and Unemployment Within Job Spells, 1976-2001 Collective Bargaining Coverage

\begin{tabular}{|c|c|c|c|c|c|}
\hline & $\begin{array}{l}\text { Contemporaneous } \\
\text { unemployment } \\
\text { rate }\end{array}$ & $\begin{array}{l}\text { Unemployment } \\
\text { at start of job }\end{array}$ & $\begin{array}{l}\text { Minimum } \\
\text { unemployment } \\
\text { rate since job } \\
\text { start }\end{array}$ & $\begin{array}{l}\text { Maximum } \\
\text { unemployment } \\
\text { rate since job } \\
\text { start }\end{array}$ & $\begin{array}{l}\text { No. of } \\
\text { individuals } \\
\text { (observations) }\end{array}$ \\
\hline \multicolumn{6}{|c|}{$\begin{array}{l}\text { Job spells } \\
\end{array}$} \\
\hline $\begin{array}{l}\text { Males } \\
\text { covered }\end{array}$ & $\begin{array}{c}-0.012 * * \\
(0.003)\end{array}$ & $\begin{array}{l}-0.001^{*} \\
(0.0006)\end{array}$ & $\begin{array}{c}-0.0006 \\
(0.001)\end{array}$ & $\begin{array}{c}0.003 \\
(0.002)\end{array}$ & $\begin{array}{c}57427 \\
(245600)\end{array}$ \\
\hline $\begin{array}{l}\text { Males } \\
\text { uncovered }\end{array}$ & $\begin{array}{c}-0.014 * * \\
(0.003)\end{array}$ & $\begin{array}{l}-0.0005 \\
(0.001)\end{array}$ & $\begin{array}{l}-0.003 \\
(0.002)\end{array}$ & $\begin{array}{l}0.0005 \\
(0.002)\end{array}$ & $\begin{array}{c}78479 \\
(357217)\end{array}$ \\
\hline $\begin{array}{l}\text { Females } \\
\text { covered }\end{array}$ & $\begin{array}{c}-0.016^{* *} \\
(0.004)\end{array}$ & $\begin{array}{l}-0.002 * \\
(0.0007)\end{array}$ & $\begin{array}{l}-0.002 \\
(0.001)\end{array}$ & $\begin{array}{c}0.004 \\
(0.002)\end{array}$ & $\begin{array}{c}37292 \\
(156633)\end{array}$ \\
\hline $\begin{array}{l}\text { Females } \\
\text { uncovered }\end{array}$ & $\begin{array}{c}-0.012 * * \\
(0.002)\end{array}$ & $\begin{array}{l}0.002 * * \\
(0.0007)\end{array}$ & $\begin{array}{c}-0.006 * * \\
(0.001)\end{array}$ & $\begin{array}{c}-0.004 * * \\
(0.001)\end{array}$ & $\begin{array}{c}49209 \\
(202071)\end{array}$ \\
\hline \multicolumn{6}{|c|}{ Employer spells } \\
\hline $\begin{array}{l}\text { Males } \\
\text { covered }\end{array}$ & $\begin{array}{c}-0.011 * * \\
(0.003)\end{array}$ & $\begin{array}{c}-0.0 \\
(0.0008)\end{array}$ & $\begin{array}{r}-0.0007 \\
(0.001)\end{array}$ & $\begin{array}{c}0.002 \\
(0.002)\end{array}$ & $\begin{array}{c}41374 \\
(213496)\end{array}$ \\
\hline $\begin{array}{l}\text { Males } \\
\text { uncovered }\end{array}$ & $\begin{array}{c}-0.011 * * \\
(0.003)\end{array}$ & $\begin{array}{l}0.003 * \\
(0.001)\end{array}$ & $\begin{array}{c}-0.006 * * \\
(0.002)\end{array}$ & $\begin{array}{l}-0.003 \\
(0.002)\end{array}$ & $\begin{array}{c}63202 \\
(324479)\end{array}$ \\
\hline $\begin{array}{l}\text { Females } \\
\text { covered }\end{array}$ & $\begin{array}{c}-0.014 * * \\
(0.004)\end{array}$ & $\begin{array}{l}0.003 * * \\
(0.0006)\end{array}$ & $\begin{array}{c}-0.009 * * \\
(0.001)\end{array}$ & $\begin{array}{l}-0.002 \\
(0.002)\end{array}$ & $\begin{array}{c}27933 \\
(137614)\end{array}$ \\
\hline $\begin{array}{l}\text { Females } \\
\text { uncovered }\end{array}$ & $\begin{array}{c}-0.012 * * \\
(0.002)\end{array}$ & $\begin{array}{l}0.002 * * \\
(0.0007)\end{array}$ & $\begin{array}{c}-0.006 * * \\
(0.001)\end{array}$ & $\begin{array}{c}-0.005 * * \\
(0.001)\end{array}$ & $\begin{array}{c}39759 \\
(183263)\end{array}$ \\
\hline
\end{tabular}

Notes: See notes to Table 3. Second stage estimates are derived from between 365 and 377 observations. 
Table 8: Real Wage Sequences within Job Spells, 1976 - 2001

\begin{tabular}{|c|c|c|c|c|c|c|}
\hline MALES & & & & & & \\
\hline Within-spell & & Percent & ges by sp & lengths & & \\
\hline wage sequences & $1-5$ & 6- 10 & $11-15$ & $16-20$ & $>20$ & Total \\
\hline $\begin{array}{l}\text { Downwardly } \\
\text { rigid }\end{array}$ & 36.3 & 9.0 & 3.0 & 1.3 & 0 & 23.4 \\
\hline Upwardly rigid & 14.0 & 0.5 & 0 & 0 & 0 & 8.0 \\
\hline Constant & 2.8 & 0.1 & 0 & 0 & 0 & 1.6 \\
\hline $\begin{array}{l}\text { Both increases } \\
\text { and decreases }\end{array}$ & 47.0 & 90.4 & 97.0 & 98.7 & 100.0 & 67.0 \\
\hline $\begin{array}{l}\text { Total } \\
\text { (No. of spells) }\end{array}$ & $\begin{array}{c}100.0 \\
(275268)\end{array}$ & $\begin{array}{c}100.0 \\
(133414)\end{array}$ & $\begin{array}{c}100.0 \\
(54778)\end{array}$ & $\begin{array}{c}100.0 \\
(17344)\end{array}$ & $\begin{array}{l}100.0 \\
(5865)\end{array}$ & $\begin{array}{c}100.0 \\
(486669)\end{array}$ \\
\hline FEMALES & & & & & & \\
\hline Within-spell & & Percent & ges by sp & lengths & & \\
\hline wage sequences & $1-5$ & 6- 10 & $11-15$ & $16-20$ & $>20$ & Total \\
\hline $\begin{array}{l}\text { Downwardly } \\
\text { rigid }\end{array}$ & 44.9 & 15.2 & 5.4 & 1.5 & 0 & 33.0 \\
\hline Upwardly rigid & 11.4 & 0.5 & 0.1 & 0 & 0 & 7.4 \\
\hline Constant & 2.9 & 0.04 & 0 & 0 & 0 & 1.9 \\
\hline $\begin{array}{l}\text { Both increases } \\
\text { and cuts }\end{array}$ & 40.8 & 84.4 & 94.6 & 98.5 & 100.0 & 57.7 \\
\hline $\begin{array}{l}\text { Total } \\
\text { (No. of spells) }\end{array}$ & $\begin{array}{c}100.0 \\
(167620)\end{array}$ & $\begin{array}{c}100.0 \\
(66810)\end{array}$ & $\begin{array}{c}100.0 \\
(20989)\end{array}$ & $\begin{array}{c}100.0 \\
(5595)\end{array}$ & $\begin{array}{l}100.0 \\
(1190)\end{array}$ & $\begin{array}{c}100.0 \\
(262204)\end{array}$ \\
\hline
\end{tabular}


Table 9: Real Wage Sequences within Employer Spells, 1976 - 2001

\begin{tabular}{|c|c|c|c|c|c|c|}
\hline MALES & & & & & & \\
\hline Within-spell & & Percent & ges by sp & lengths & & \\
\hline wage sequences & $1-5$ & 6- 10 & $11-15$ & $16-20$ & $>20$ & Total \\
\hline $\begin{array}{l}\text { Downwardly } \\
\text { rigid }\end{array}$ & 34.6 & 9.2 & 3.0 & 1.7 & 0.3 & 19.6 \\
\hline Upwardly rigid & 13.4 & 0.3 & 0 & 0 & 0 & 6.5 \\
\hline Constant & 2.3 & 0.1 & 0 & 0 & 0 & 1.1 \\
\hline $\begin{array}{l}\text { Both increases } \\
\text { and decreases }\end{array}$ & 49.8 & 90.4 & 97.0 & 98.3 & 99.7 & 72.8 \\
\hline $\begin{array}{l}\text { Total } \\
\text { (No. of spells) }\end{array}$ & $\begin{array}{c}100.0 \\
(254405)\end{array}$ & $\begin{array}{c}100.0 \\
(150374)\end{array}$ & $\begin{array}{c}100.0 \\
(80444)\end{array}$ & $\begin{array}{c}100.0 \\
(33373)\end{array}$ & $\begin{array}{l}100.0 \\
(14570)\end{array}$ & $\begin{array}{c}100.0 \\
(533166)\end{array}$ \\
\hline FEMALES & & & & & & \\
\hline Within-spell & & Percent & ges by sp & lengths & & \\
\hline wage sequences & $1-5$ & 6- 10 & $11-15$ & $16-20$ & $>20$ & Total \\
\hline $\begin{array}{l}\text { Downwardly } \\
\text { rigid }\end{array}$ & 42.8 & 15.3 & 5.3 & 2.1 & 0.5 & 27.9 \\
\hline Upwardly rigid & 10.7 & 0.4 & 0.03 & 0 & 0 & 5.8 \\
\hline Constant & 2.4 & 0.01 & 0 & 0 & 0 & 1.3 \\
\hline $\begin{array}{l}\text { Both increases } \\
\text { and cuts }\end{array}$ & 44.1 & 84.3 & 94.7 & 97.9 & 99.5 & 65.1 \\
\hline $\begin{array}{l}\text { Total } \\
\text { (No. of spells) }\end{array}$ & $\begin{array}{c}100.0 \\
(155423)\end{array}$ & $\begin{array}{l}100.0 \\
(84203)\end{array}$ & $\begin{array}{c}100.0 \\
(36872)\end{array}$ & $\begin{array}{c}100.0 \\
(12637)\end{array}$ & $\begin{array}{c}100.0 \\
(4178)\end{array}$ & $\begin{array}{c}100.0 \\
(293313)\end{array}$ \\
\hline
\end{tabular}

